EXCRETION OF ${ }^{137}$ CS FROM SILVER PRUSSIAN CARP (CARASSIUS GIBELIO) AT $5^{\circ} \mathrm{C}$ WATER TEMPERATURE O. KASHPAROVA, PhD student ${ }^{1,2^{*}}$

Yu. KHOMUTININ, Doctor of Agricultural Sciences, Senior Researcher ${ }^{1}$ H.-C. TEIEN, $\mathrm{PhD}^{2}$

\author{
I. GUDKOV, Doctor of Biological Sciences, Professor ${ }^{1}$ \\ ${ }^{1}$ National University of Life and Environmental Sciences of Ukraine \\ ${ }^{2}$ Center for Environmental Radioactivity (CERAD), Norwegian University of \\ Life Sciences, P.O. Box 5003, N-1432, As, Norway \\ E-mail: elena.kashparova@gmail.com
}

https://doi.org/10.31548/dopovidi2020.04.008

Abstract. After the accidents at Chernobyl and Fukushima-1 nuclear power plants, the radioactive contamination of fish can still exceed the permissible levels of radionuclides in food. In order to predict the radioactive contamination of fish, the parameterization of mathematical models is the basis for radiation protection of humans and the environment. Until recently, there were no parameters of radiocaesium metabolism which is the rate of uptake and excretion of radionuclides from fish at a water temperature below $8-10^{\circ} \mathrm{C}$ during winter season.

The aim of this work was to determine the rate of ${ }^{137} \mathrm{Cs}$ excretion (biological halflife) from the silver Prussian carp (Carassius gibelio) at a water temperature of $5 \pm 1^{\circ}$ $C$ under controlled conditions in aquarium.

As a result of experimental studies, the values of the ${ }^{137} \mathrm{Cs}$ biological half-life were obtained from the silver Prussian carp (392 \pm 206 days) in the absence of feeding at a water temperature of $5 \pm 1{ }^{\circ} \mathrm{C}$. That corresponds to the values previously obtained by us in similar conditions after the radioactive contamination of fish in the environment of the Chernobyl Exclusion Zone $-433 \pm 162$ days. When describing the dynamics of a decrease of the ${ }^{137}$ Cs activity concentration in the body of silver Prussian carp with double exponential dependence, the proportion of the fast component of the radionuclide content decrease was $19 \pm 3 \%$. In this case, the fast and slow rates of ${ }^{137}$ Cs excretion from the body of the fish were equal to $0.3 \pm 0.2$ days $^{-1}$ and $0.0004 \pm 0.0003$ days ${ }^{-1}$, respectively.

The results obtained in the work show that the level of radioactive contamination of fish will be constant during the winter season. And its seasonal decrease in winter (according to the sawtooth dependence), usually expected out of projected estimates, does not happen. That was also confirmed by the results and experimental data obtained in the environment of the Chernobyl Exclusion Zone.

Keywords: ${ }^{137}$ Cs, radioecology, Carassius gibelio, Chernobyl accident, radioactive contamination, permissible levels, the rate of radionuclide excretion

\footnotetext{
* Supervisor - Professor I.N. Gudkov and PhD H.-C. Teien
} 
Кашпарова О. В., Хомутінін Ю. В., Теіен Х.-К., Гудков І. М.

Introduction. For many years, the activity concentration of ${ }^{137} \mathrm{Cs}$ in the fish organism exceeds the permissible levels of radionuclides in food products DR$2006-150 \mathrm{~Bq} \mathrm{~kg}^{-1}$ in the territory contaminated as a consequence of the Chernobyl accident [1-3].

There is a direct dependence between the level of fish metabolism and the metabolism of individual elements on water temperature $[4,5]$. Predictive analysis made by using generally accepted mathematical models showed that a decrease in the activity concentration of radiocaesium in fish should be observed with a factor of 1.5-2 in winter at a water temperature below $10{ }^{\circ} \mathrm{C}$ in comparison with the summer period $[2,5,6]$. This is due to a decrease of the ${ }^{137} \mathrm{Cs}$ uptake by fish with consumed food in winter, since the feeding is practically stopped for such fish species as silver Prussian carp, rudd and others, during November-March at a water temperature below $8-10{ }^{\circ} \mathrm{C}$ in the environment of the northern part of Ukraine [7]. However, it is believed that the rate of excretion of radiocaesium from the body of fish does not change significantly during the year. Recent studies of aquarium experiments have shown that the biological half-lives of ${ }^{137} \mathrm{Cs}$ (the time during which the activity concentration of the radionuclide is reduced by 2 times) from the body of silver Prussian carp brought from the Chernobyl Exclusion Zone (ChEZ), at water temperatures of $5{ }^{\circ} \mathrm{C}$ and $22{ }^{\circ} \mathrm{C}$ were significantly different and were demonstrated during $433 \pm 162$ days and $78 \pm 4$ days, respectively [8]. In this case, the radioactive contamination of silver Prussian carp occurred in natural conditions in the reservoir of the ChEZ through the digestive system of fish with food, mainly in the summer [9]. It was shown that the activity concentration of ${ }^{137} \mathrm{Cs}$ in the body of fish will be two orders of magnitude lower in the case of radioactive contamination of water bodies in the winter at a water temperature below $8-10{ }^{\circ} \mathrm{C}$ in the absence of fish feeding and the entry of radionuclides into the body directly from the water through gills and skin, than in the case with radioactive pollution of water in the summer [9].

To confirm this and clarify forecast estimates in the event of radiation accidents, it is necessary to evaluate the rate of radiocaesium excretion from silver Prussian carp at a water temperature of $5{ }^{\circ} \mathrm{C}$ after it penetrates into fish directly from radioactively contaminated water (not through the digestive system with food).

Determination of the values of the excretion rate (half-life) of radionuclides from the fish organism is also of practical importance as a countermeasure to reduce the level of radioactive contamination of fish [10]. From the end of 2014 to the present, the water level of the Chernobyl NPP cooling pond has decreased by 5-6 meters, which has led to which has led to the following changes : the area of the reservoir has decreased and the density 
Кашпарова О. В., Хомутінін Ю. В., Теіен Х.-К., Гудков І. М.

of fish in the formed lakes has increased [11]. In this regard, there were proposals to transfer fish from the Chernobyl cooling pond into the Pripyat River. However, the lack of data on the real values of the radionuclides elimination rates at different temperatures in natural conditions, feeding regimes and weight changes of the fish did not allow to optimize the time for the fish transferring and the need for fattening with clean feed before that.

The aim of the study is to determine the excretion rate (biological half-life) of ${ }^{137} \mathrm{Cs}$ from the body of silver Prussian carp at a water temperature of $5 \pm 1{ }^{\circ} \mathrm{C}$. To achieve this, an aquarium experiment was conducted to measure the dynamics of ${ }^{137} \mathrm{Cs}$ in the fish body after their radioactive contamination directly from water in the absence of feeding [9].

\section{Materials and methods of} research. The subject of this study was the wild silver Prussian carp with the weight $M(0)=15 \pm 2 \mathrm{~g}$ and the absolute length $\mathrm{L}=10.1 \pm 0.4 \mathrm{~cm}$, taken from the reservoir near s. Rozhny (N 50.663383, E $30.722267^{\circ}$ ). Before the experiment, fish were transferred in two 9-liter aquariums ( 7 fish per aquarium) located in a refrigerator at a water temperature of $5 \pm 1{ }^{\circ} \mathrm{C}$ for 14 days to proceed the radioactive contamination. The activity concentration of ${ }^{137} \mathrm{Cs}$ in aquarium water was $1 \mathrm{kBq}{ }^{137} \mathrm{Cs} / 1$. During 14 days of radioactive contamination and 77 days of the entire experiment for the ${ }^{137} \mathrm{Cs}$ excretion study, the silver Prussian carp were without food, since at a water temperature below $8-10{ }^{\circ} \mathrm{C}$ in the natural conditions of Ukrainian Polissia, silver Prussian carp stop feeding [7]. Water for aquariums with ${ }^{137} \mathrm{Cs}$ content less than $0.01 \mathrm{~Bq}^{-1}$ was always taken from the same natural floodplain lake near the Dnieper within Kozyn village area $\left(\mathrm{N} 50.224737^{\circ}, \mathrm{E} 30.670096^{\circ}\right)$ as it was similar in chemical composition to water in Hlyboke Lake in the ChEZ $\left({ }^{39} \mathrm{~K}-1.4 \pm 0.5 \mathrm{mg} \mathrm{l}^{-1} ;{ }^{44} \mathrm{Ca}-30 \pm 1 \mathrm{mg} \mathrm{l}^{-}\right.$ ${ }^{1} ;{ }^{88} \mathrm{Sr}-0.11 \pm 0.04 \mathrm{mg} \mathrm{l}^{-1} ;{ }^{133} \mathrm{Cs}-$ $5 \pm 3 \mathrm{ng} \mathrm{l}^{-1}$ ) [9]. Continuous monitoring and maintaining a constant water temperature of $5 \pm 1^{\circ} \mathrm{C}$ in aquariums was realized by using thermoregulators (DigiTOP TP-1, Ukraine) with precision of $0.1{ }^{\circ} \mathrm{C}$ and automatic sensors Onset HOBO UA-001-64 Waterproof Pendant 64K Temperature Data Loggers (Onset Computer Corporation, USA) immersed in the water. The aquarium water was constantly filtered by submersible filters (AquaEl Fan Mini Plus, Poland) that were cleaned daily. Air into the aquarium water was supplied with compressors and spray guns (Tetra APS 50 and Tetra AS50, Germany).

Before the beginning of the experiment and every 14 days after the radioactive contamination of fish directly into the water, the activity concentration of ${ }^{137} \mathrm{Cs}$ was measured in each group of 7 live fish. After that, blood samples were taken from 7 fish from one aquarium for measuring the glucose level (Contour Plus, Bayer Healthcare AG, Germany) and the 
Кашпарова О. В., Хомутінін Ю. В., Теіен Х.-К., Гудков І. М.

amount of hemoglobin (HemoCue ${ }^{\circledR} \mathrm{Hb}$ $201+$, USA). The ${ }^{137} \mathrm{Cs}$ activity was also measured directly in muscle tissues gills, skin, and intestines. The remaining 7 fish were moved to a similar aquarium with clean water $(t=0)$ to begin the intravital measurements of dynamics of decrease in ${ }^{137} \mathrm{Cs}$ activity $\left(\mathrm{A}_{\mathrm{f}}(\mathrm{t}), \mathrm{Bq}\right)$. During the experiment, the replacement of aquarium water was carried out) every 7-12 days after its chemical composition had been measured (Tetra Test 6in1, Germany).

Measurements of the ${ }^{137} \mathrm{Cs}$ activity in live fish $\left(A_{f}(t), \mathrm{Bq}\right)$ and in the water of the aquariums before its replacement were carried out in Marinelli vessels with a volume of 1 liter every 3-12 days. Fish tissue samples were measured in $10 \mathrm{~cm}^{3}$ plastic vials on a lowbackground gamma-spectrometric complex with the high-purity germanium detector GEM-30185 («EG \& G ORTEC», USA) having energy resolution of $1,78 \mathrm{keV}$ for the $1,33 \mathrm{MeV}$ line of 60Co in low-background passive lead protection. To measure the ${ }^{137} \mathrm{Cs}$ activity in live fish, 7 fish from each aquarium were placed in a Marinelli vessel with water. During the measurements the water temperature in Marinelli vessels was equal to the temperature of the aquarium water $(5 \pm 1$ ${ }^{\circ} \mathrm{C}$ ), and its total weight was brought to

$$
C_{f}(t) / C_{f}(t=0)=\exp \left(-\left(k_{b}+\lambda\right) \cdot t\right)
$$

where $k_{b}$ is the rate of ${ }^{137} \mathrm{Cs}$ excretion from fish, day ${ }^{-1}$;
$1000 \mathrm{~g}$. The ${ }^{137} \mathrm{Cs}$ activity in the samples was measured on the total absorption peak for the $661.6 \mathrm{keV}$ gamma line during 600-1000 seconds. Repeated measurements of the counting rates from live fish, made on the total absorption peak, showed that the scatter of the measurements did not exceed $20 \%$. This is due to the different positions of fish in the Marinelli vessel during the measurements. After the experiment was completed, the correlation dependence was obtained between the ${ }^{137} \mathrm{Cs}$ activity concentration in fish samples and the pulse count rate. The weight of fish $(M(t)$, $\mathrm{g}$ ) was estimated by the mass difference of the Marinelli vessel with water and fish, as well as without it, the ${ }^{137} \mathrm{Cs}$ activity concentration measured in each case.

To measure the ${ }^{137} \mathrm{Cs}$ activity in water along with selected fish samples, the calibration reference sources with known activity and the same geometry were used.

The weight of the samples was measured on the balance KERN pfb with an accuracy of $0.01 \mathrm{~g}$ and the balance AXIS AD200 with an accuracy of $0.001 \mathrm{~g}$.

The exponential dependence was used for a mathematical description of the dynamics of decrease in the ${ }^{137}$ Cs activity concentration in fish $\left(C_{f}(t)=A_{f}(t) * 1000 / M(t), \mathrm{Bq} \mathrm{kg}^{-1}\right)$ during $t$ (days) $[6,8]$ :

$$
T_{1 / 2}^{b i o}=\ln (2) / k_{b} \quad-\quad \text { biological }
$$

half-life of ${ }^{137} \mathrm{Cs}$, day; 
Кашпарова О. В., Хомутінін Ю. В., Теіен Х.-К., Гудков І. М.

$\lambda=6.3 \cdot 10^{-5}$ day $^{-1}-$ decay constant ${ }^{137} \mathrm{Cs}$.

Also, double exponential dependence is often used to describe the dynamics of decrease in activity concentration in animals [12]:

$$
\frac{C_{f}(t)}{C_{f}(t=0)}=a \cdot \exp \left(-k_{b}^{f} \cdot t\right)+(1-a) \cdot \exp \left(-\left(k_{b}^{s}+\lambda\right) \cdot t\right)
$$

where $\mathrm{a}$ is the proportion of the fast component of the radionuclide content reduction;

$k_{b}^{f}$ and $k_{b}^{s}$ are fast and slow rates of ${ }^{137} \mathrm{Cs}$ excretion from the body of fish, day $-1$

Results and discussion. After the fish contamination for 14 days in water with activity concentration of $1 \mathrm{~Bq} \mathrm{ml}^{-1}$ at the start of the experiment, the average activity concentration of ${ }^{137} \mathrm{Cs}$ in silver Prussian carp muscle tissue $(\mathrm{N}=7)$ was $\mathrm{Cf}(\mathrm{t}=0)=630 \pm 113 \quad \mathrm{~Bq} \quad \mathrm{~kg}^{-1} \quad$ natural weight. The activity concentration of ${ }^{137} \mathrm{Cs}$ in the gills was $730 \pm 70 \mathrm{~Bq} \mathrm{~kg}^{-1}$, in the skin - $470 \pm 70 \mathrm{~Bq} \mathrm{~kg}^{-1}$ and in the intestines $-990 \pm 100 \mathrm{~Bq} \mathrm{~kg}$. The average glucose level in the blood of the silver Prussian carp was $5.8 \pm 1.7 \mathrm{mmol} / 1$ and the amount of hemoglobin was $8.6 \pm 0.6 \mathrm{~g} / 1$.

During the experiment, the activity concentration of ${ }^{137} \mathrm{Cs}$ in aquarium water was at the level of the minimum detectable activity concentration below 2 $\mathrm{Bq}^{-1}$. This did not allow to use the results to assess correctly the leakage of radiocaesium from the body of fish into water due to the high measurement errors of its activity. The most accurate results were obtained by intravital measurement of ${ }^{137} \mathrm{Cs}$ activity in dynamics directly in the live fish.

The relative dynamics of changes in the ${ }^{137} \mathrm{Cs}$ activity concentration is shown in Fig. 1. The results were obtained by intravital measurements of the activity of ${ }^{137} \mathrm{Cs}$ from the muscle tissue of silver Prussian carp living in pure water for 77 days. At the end of the experiment, the average weight of the silver Prussian carp was $M(t=77)=13 \pm 2 \mathrm{~g}$, the ${ }^{137} \mathrm{Cs}$ activity concentration in the muscle tissue $(\mathrm{N}=7)$ was $C_{f}(t=77)=490 \pm 85 \mathrm{~Bq}$ $\mathrm{kg}^{-1}$, in the gills $-350 \pm 67 \mathrm{~Bq} \mathrm{~kg}^{-1}$, in the skin - 458 $\pm 92 \mathrm{~Bq} \mathrm{~kg}^{-1}$ and in the intestines $-533 \pm 75 \mathrm{~Bq} \mathrm{~kg}^{-1}$.

During the experiment, there was no statistically significant change in acidity $(\mathrm{pH})$, hardness $(\mathrm{KH}$ and $\mathrm{GH})$ and concentration of ${ }^{23} \mathrm{Na},{ }^{24} \mathrm{Mg},{ }^{39} \mathrm{~K},{ }^{44} \mathrm{Ca}$, ${ }^{88} \mathrm{Sr},{ }^{133} \mathrm{Cs},{ }^{238} \mathrm{U}$ in the aquarium water $[8$, 9]. Also, the content of nitrites $\left(\mathrm{NO}_{2}{ }^{-}\right)$, nitrates $\left(\mathrm{NO}_{3}{ }^{-}\right)$and chlorine $\left(\mathrm{Cl}^{2}\right)$ in the water did not exceed permissible levels.

Using the method of least squares, we determined the rates of ${ }^{137} \mathrm{Cs}$ excretion from the muscle tissue of silver Prussian carp in the exponential dependence (equation 1) - Fig. 1:

$$
k_{b}=0.0018 \pm 0.0009 \mathrm{day}^{-1}
$$

and double exponential dependence (equation 2):

$$
a=0.19 \pm 0.03 ; k_{b}^{f}=0.3 \pm 0.2 d a y^{-1} ; k_{b}^{s}=0.0004 \pm 0.0003 d a y^{-1} .
$$




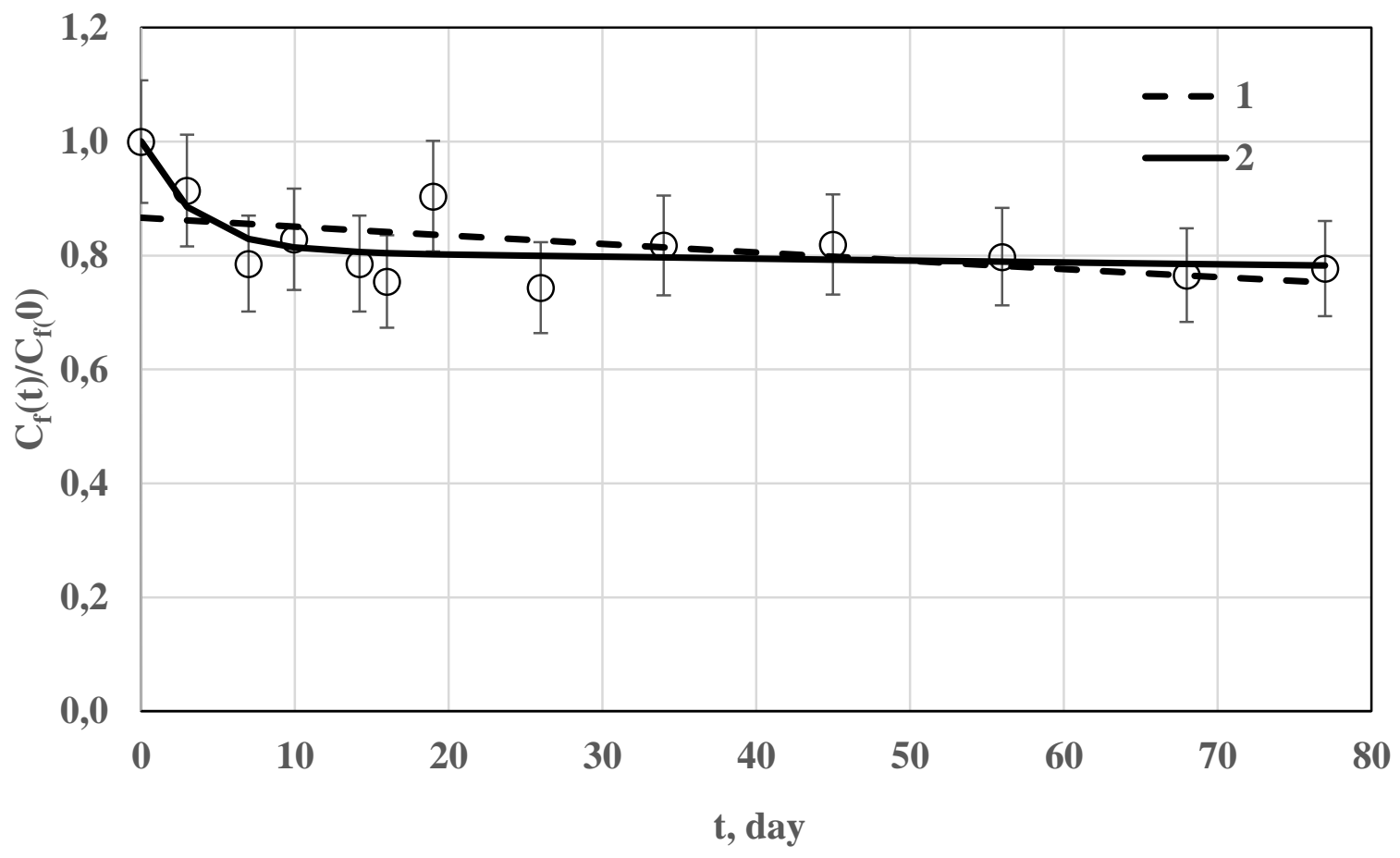

Fig. 1 Dynamics of the relative activity concentration of ${ }^{137} \mathrm{Cs}$ in the muscle tissue of silver Prussian carp, as well as the corresponding theoretical exponential (1 equation 1 ) and double exponential dependence ( 2 - equation 2$)$.

Equation 2 describes better the experimental data (correlation coefficient is 0.83 ) if compare to the exponential dependence in equation 1 (correlation coefficient is 0.50 ), which is also typical of other organisms [13].

Our value of the biological half-life of ${ }^{137} \mathrm{Cs}$ from the muscle tissue of silver Prussian carp $\left(T_{1 / 2}^{b i o}=392 \pm 206\right.$ day $)$ corresponds to previously obtained values of the radioactive contamination of fish in the conditions similar to the $\mathrm{ChEZ}$ natural environment $-T_{1 / 2}^{b i o}=433 \pm 162$ day [8].

When the biological half-life of the ${ }^{137} \mathrm{Cs}$ slow component from the body of fish lasts more than 400 days and a fraction of the fast component of a radionuclide content decrease is about
$20 \%$, a monotonic decrease of the fish radioactive contamination in 1.5-2 times cannot occur in winter $[2,5]$. If, under these conditions, the fish continue the insignificant consumption of radioactively contaminated feed, then there will be no decline in the radioactive contamination of fish in the winter. Therefore, the level of radioactive contamination of fish will will be permanent in the winter, which does not correspond to the sawtooth dependence usually obtained with projected estimates $[2,5]$. This conclusion is also confirmed by experimental data obtained in real-time conditions of the ChEZ [14].

\section{Conclusion}

As a result of experimental studies, the values of the excretion rate of ${ }^{137} \mathrm{Cs}$ from the Prussian carp (C. gibelio) in the 
Кашпарова О. В., Хомутінін Ю. В., Теіен Х.-К., Гудков І. М.

absence of feeding at a water temperature of $5 \pm 1{ }^{\circ} \mathrm{C}$ were obtained $k_{b}=0.0018 \pm 0.0009$ day $^{-1}$ $\left(T_{1 / 2}^{\text {bio }}=392 \pm 206\right.$ day $)$.

That corresponds to previously obtained values in similar conditions after the radioactive contamination of fish in the environment of the ChEZ $-T_{1 / 2}^{b i o}=$ $433 \pm 162$ days (Kashparova et al., 2019).

When describing the dynamics of a decrease in the activity concentration of ${ }^{137} \mathrm{Cs}$ in an organism of silver Prussian carp by an exponential dependence (equation 2), the fraction of the fast component of the decrease in the content of radionuclide was $a=0.19 \pm 0.03$. In this case, the fast and slow rates of ${ }^{137} \mathrm{Cs}$ excretion from the body of the fish were equal to $k_{b}^{f}=0.3 \pm 0.2 \mathrm{day}^{-1}\left(T_{\frac{1}{2}}^{\text {bio }}=\right.$

\section{References}

1. Khomutinin Yu.V. Dependence of ${ }^{137} \mathrm{Cs}$ and ${ }^{90} \mathrm{Sr}$ accumulation rates by fish on potassium and calcium in a freshwater reservoir / Yu.V. Khomutinin, V.A. Kashparov, A.V. Kuzmenko // Radiation biology. Radioecology. - 2011. - №51(3). - P. 374-384 (Russ).

2. The forecast of the dynamics and risk of exceeding the permissible content of ${ }^{137} \mathrm{Cs}$ and ${ }^{90} \mathrm{Sr}$ in the fish of the Kiev reservoir at the late phase of the Chernobyl accident / Yu.V. Khomutinin, V.A. Kashparov, A.V. Kuzmenko et al. // Radiation biology. Radioecology. 2013. - №53(4). - P. 411-427 (Russ).

3. Radionuclides in native fish species of the Chernobyl Exclusion Zone / A.Ye. Kaglyan, D.I. Gudkov, V.G. Klenus et al. // Nuclear physics and energy. - 2012. - №13(3). - P.306-315 (Russ).

4. Katkov A. E. Influence of water temperature on the accumulation of radionuclides by fish. Problems of radioecology of cooling ponds of nuclear power
$2.3 \pm 1.5$ day) and $k_{b}^{s}=0.0004 \pm$ 0.0003 day $^{-1}\left(T_{1 / 2}^{b i o}=1733 \pm\right.$

1300 days), respectively.

\section{Acknowledgments}

This work was supported by the National University of Life and Environmental Sciences of Ukraine (No 110/1-pr-2019, State registration number 0119U100844) under the project “ Determination of maximum permissible concentrations of radionuclides in reservoirs based on caesium and strontium metabolism in fish"; and the Norwegian Centre for International Cooperation in Education (SiU) through the «Joint Ukrainian-Norwegian education program in Environmental Radioactivity» (grant CPEA2015/10108).

plants / A.E. Katkov, D.I. Gusev, A.V. Dzebunov et al. // Sat articles. Sverdlovsk. UC AN USSR. - 1978. - P. 70-75.

5. Kryshev A. I. Calculation model of fish contamination ${ }^{137} \mathrm{Cs}$ and its application for Lake Kozhanovsky (Bryansk region) / A.I. Kryshev, I.N. Ryabov // Radiation biology. Radioecology. - 2005. - №45(3). - P.338-345 (Russ).

6. Smith J.T. Modelling the dispersion of radionuclides following short duration releases to rivers Part 2. Uptake by fish / J.T. Smith // Science of the Total Environment. - 2006. P.502-518.

7. Polyakova N.I. Features of ${ }^{137} \mathrm{Cs}$ uptake in fish of different trophic levels from water bodies contaminated with radionuclides as a result of the Chernobyl accident, abstract of thesis. kb by special 03.00.10-ichthyology, Moscow: Institute of Ecology and Evolution A.N. Severtsev RAS. - 2008. - P. 25 (Russ).

8. Dynamics of the ${ }^{137} \mathrm{Cs}$ excretion from Prussian carp (Carassius gibelio) at different 
Кашпарова О. В., Хомутінін Ю. В., Теіен Х.-К., Гудков І. М.

water temperatures / O. Kashparova, H.-C.

Teien, S. Levchuk et al. // Nuclear physics and atomic energy. - 2019. - №20(4). - P.411-419 https://doi.org/10.15407/jnpae2019.04.411 (Russ).

9. Dynamics of ${ }^{137} \mathrm{Cs}$ uptake from water to Prussian carp (Carassius gibelio) / O. Kashparova, H.-C. Teien, S. Levchuk et al. // Nuclear Physics and Atomic Energy. - 2020. № $\quad 21(1)$. $\quad-\quad$ P.64-74. https://doi.org/10.15407/jnpae2020.01.064 (Russ).

10. Kaglyan A.Yu., Gudkov D.I, Sizonenko V.P, Yurchuk L.P. (2018). Patent No. 128443. Method of purification of Carassius Gibelio Bloch from ${ }^{137} \mathrm{Cs}$ to hygienic radiation-safe levels. publ. 25.09.2018, bul. № 18.

11. Environmental Impact Assessment of the Drawdown of the Chernobyl NPP Cooling Pond as a Basis for Its Decommissioning and Remediation. IAEA-TECDOC-1886. - 2019. -
International Atomic Energy Agency. Vienna. - P. 186.

12. Handbook of parameter values for the prediction of radionuclide transfer in terrestrial and fresh-water environments. IAEA-TRS-472. - 2010. - P.194. http://wwwpub.iaea.org/MTCD/publications/PDF/trs472_ web.pdf

13. Fesenko S., Howard B.J. Guidelines for Remediation Strategies to Reduce the Radiological Consequences of Environmental Contamination, Technical Editors / S. Fesenko, B.J. Howard : International Atomic Energy Agency, Vienna, IAEA TRS 475. - 2012. P.183. $\quad$ https://wwwpub.iaea.org/MTCD/Publications/PDF/trs475 web.pdf

14. Uptake of ${ }^{137} \mathrm{Cs}$ with walleye (Lucioperca lucioperca L.) / Zarubin O.L, Kostyuk V.A, Malyuk I.A et al. // Nuclear physics and energy. - 2012. - № 13(2). P.175-181 (Russ).

\section{ВЫВЕДЕНИЯ ${ }^{137}$ Сs ИЗ ОРГАНИЗМА КАРАСЯ СЕРЕБРЯНОГО (CARASSIUS GIBELIO) ПРИ ТЕМПЕРАТУРЕ ВОДЫ $5^{\circ} \mathrm{C}$ Е. В. Кашпарова, Ю. В. Хомутинин, Х.-К. Теиен, И. Н.Гудков}

Аннотация. После Чернобыльской аварии и аварии на АЭС Фукушима-1 радиоактивное загрязнение рыб до настоящего времени может превышать допустимые уровни содержания радионуклидов в рыбных продуктах питания человека. Параметризачия математических моделей с иелью прогнозирования радиоактивного загрязнения рыб является одной из основ для радиационной защиты человека и окружающей среды. До последнего времени отсутствовали параметры метаболизма радиочезия - скорости поступления и выведения радионуклидов из организма рыб в зимний период при температуре воды ниже $8-10^{\circ} \mathrm{C}$.

Целью настоящей работы было определение скорости выведения (периода биологического полувыведения) ${ }^{137}$ Cs из организма карася серебряного (Carassius gibelio) при температуре воды $5 \pm 1{ }^{\circ} \mathrm{C}$ в аквариумных контролируемых условиях.

$B$ результате проведенных экспериментальных исследований были получены значения периода биологического полувыведения ${ }^{137} \mathrm{Cs}$ из организма карася серебряного (392 206 суток) в отсутствии кормления при температуре воды $5 \pm 1{ }^{\circ} \mathrm{C}$, которые равны ранее полученным нами величинам для аналогичных условий после радиоактивного загрязнения рыбы в естественных условиях

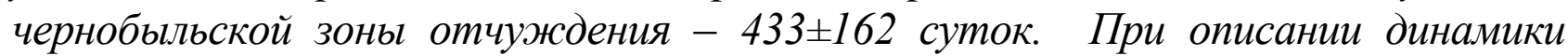
уменьшения удельной активности ${ }^{137} \mathrm{Cs}$ в организме карасей серебряных двух экспоненциальной зависимостью доля быстрой составляющей уменьшения 
Кашпарова О. В., Хомутінін Ю. В., Теіен Х.-К., Гудков І. М.

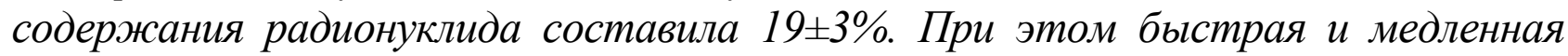
скорости выведения ${ }^{137} \mathrm{Cs}$ из организма рыбы были равнь $0.3 \pm 0.2$ сутки $и$ $0.0004 \pm 0.0003$ сутки ${ }^{-1}$, соответственно.

Полученные в работе результаты показывают, что уровень радиоактивного загрязнения рыбы в зимний период будет постоянным и его сезонное уменьшение, в зимнее время (пилообразная зависимость) обычно получаемое ранее при прогнозных оценках не должно наблюдаться, о чем свидетельствуют приведенные результаты и экспериментальные данные, полученные в реальных природных условиях чернобыльской зоны отчуждения.

Ключевые слова: ${ }^{137}$ Cs, радиоэкология, Carassius gibelio, Чернобыльская авария, радиоактивное загрязнение, допустимые уровни, скорость выведения радионуклида

\section{ВИВЕДЕННЯ ${ }^{137}$ Cs 3 ОРГАНІЗМУ КАРАСЯ СРІБНОГО (CARASSIUS GIBELIO) ПРИ ТЕМПЕРАТУРИ ВОДИ $5^{\circ} \mathrm{C}$ О. В. Кашпарова, Ю. В. Хомутінін, Х.-К. Теіен, І. М. Гудков}

Анотація. Після Чорнобильської аварії та аварї на АЕС Фукушіма-1 радіоактивне забруднення риб до теперішнього часу може перевищувати допустимі рівні вмісту радіонуклідів у рибних продуктах харчування людини. Параметризачія математичних моделей $з$ метою прогнозування радіоактивного забруднення риб є основою для радіаційного захисту людини $i$ навколишнього середовищуа. До останнього часу були відсутні параметри метаболізму радіочезію - швидкості надходження і виведення радіонуклідів 3 організму риб в зимовий період при температурі води нижче $8-10^{\circ} \mathrm{C}$.

Метою иієї роботи було визначення швидкості виведення (періоду біологічного напіввиведення) ${ }^{137}$ Cs з організму карася срібного (Carassius gibelio) при температурі води $5 \pm 1^{\circ} \mathrm{C}$ в акваріумних контрольованих умовах.

У результаті проведених експериментальних досліджень були отримані значення періоду біологічного напіввиведення ${ }^{137} \mathrm{Cs}$ з організму карася срібного (392 206 діб) без годування при температурі води $5 \pm 1{ }^{\circ} \mathrm{C}$, які відповідають раніме отриманими нами величинам для аналогічних умов після радіоактивного забруднення риби в природних умовах Чорнобильської зони відчуження - $433 \pm$ 162 діб. При описі динаміки зменшення питомої активності ${ }^{137} \mathrm{Cs}$ в організмі карасів срібних двох експоненційною залежністю частка швидкої складової

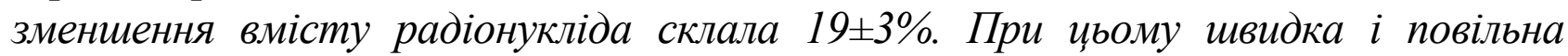
швидкості виведення ${ }^{137}$ Cs з організму риби були рівні $0.3 \pm 0.2$ діб-1 та $0.0004 \pm 0.0003$ діб-1, відповідно.

Отримані в роботі результати показують, щзо рівень радіоактивного забруднення риби в зимовий період буде постійним і його сезонне зменшення, в зимовий час (пилоподібна залежність) зазвичай отримується раніше при прогнозних оцінках, не повинно спостерігатися, про щзо свідчать наведені результати $і$ експериментальні дані, отримані в реальних природних умовах чорнобильської зони відчуження. 
Кашпарова О. В., Хомутінін Ю. В., Теіен Х.-К., Гудков I. М.

Ключові слова: ${ }^{137}$ Cs, радіоекологія, Carassius gibelio, Чорнобильська аварія, радіоактивне забруднення, допустимі рівні, ивидкість виведення радіонукліда 